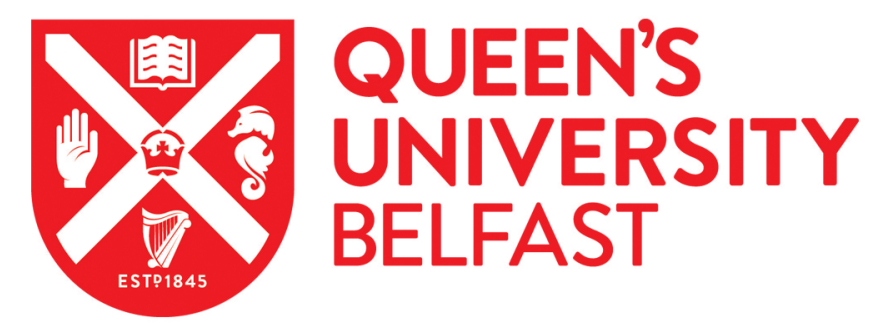

\title{
Now you see it, now you don't: On the (in)visibility of police stop and search in Northern Ireland
}

Topping, J., \& Bradford, B. (2018). Now you see it, now you don't: On the (in)visibility of police stop and search in Northern Ireland. Criminology and Criminal Justice. https://doi.org/10.1177/1748895818800742, https://doi.org/10.1177/1748895818800742

Published in:

Criminology and Criminal Justice

Document Version:

Peer reviewed version

Queen's University Belfast - Research Portal:

Link to publication record in Queen's University Belfast Research Portal

Publisher rights

(c) 2018 The Authors. This work is made available online in accordance with the publisher's policies. Please refer to any applicable terms of use of the publisher.

\section{General rights}

Copyright for the publications made accessible via the Queen's University Belfast Research Portal is retained by the author(s) and / or other copyright owners and it is a condition of accessing these publications that users recognise and abide by the legal requirements associated with these rights.

Take down policy

The Research Portal is Queen's institutional repository that provides access to Queen's research output. Every effort has been made to ensure that content in the Research Portal does not infringe any person's rights, or applicable UK laws. If you discover content in the Research Portal that you believe breaches copyright or violates any law, please contact openaccess@qub.ac.uk. 
Now you see it, now you don't: On the (in)visibility of police stop and search in Northern Ireland

John Topping, Queen's University, Belfast

Ben Bradford, Jill Dando Institute of Security and Crime Science, UCL, London

Corresponding author: Dr John Topping, 6 College Park, Queen's University, Belfast, BT7 1LP email: j.topping@qub.ac.uk telephone: 02890973630 twitter: @drjohntopping

John Topping is a lecturer in criminology at Queen's University, Belfast and Fellow of the Senator George J. Mitchell Institute for Global Peace, Security and Justice. His research interests centre around police reform, practice, and accountability, along with stop and search and public order policing. He has over a decade of research and consultancy experiences with all the policing institutions in Northern Ireland and is currently Chairperson of Community Restorative Justice Ireland.

Ben Bradford is Director of the Institute for Global City Policing at the UCL Jill Dando Institute of Security and Crime Science. His research interests include procedural justice theory, public trust, and police legitimacy. His book, Stop and Search and Police Legitimacy, was published in 2017; he is also editor, along with Beatrice Jauregui, lan Loader and Jonny Steinberg, of the SAGE Handbook of Global Policing (2016).

Word count: 8115 (includes abstract, main body, references and figures/tables). 


\begin{abstract}
Police stop and search practices have been subject to voluminous debate for over forty years in the United Kingdom. Yet critical debate related to the use of 'everyday' stop and search powers by the Police Service of Northern Ireland (PSNI) has, despite the hyper-accountable policing system of Northern Ireland, been marked by its absence. This paper presents the first ever analysis of PSNI's use of PACE-type powers - currently used at a higher rate and with poorer outcomes compared to the rest of the U.K. While it can only be considered as an elusive power, about which detailed research evidence is markedly lacking, stop and search in Northern Ireland seems to serve as a classificatory tool for PSNI to control mainly young, socio-economically marginal male populations. The paper provides new theoretical insight into stop and search as a simultaneous overt and covert practice, and speaks to wider issues of mundane police power - and practice - within highly contested and politically fractured contexts.
\end{abstract}

Keywords: stop and search; Police Service of Northern Ireland; police powers; social control 
It is almost impossible to think about Northern Irish policing without attending to the wider politics of the 'post-troubles' era, and particularly the Report of the Independent Commission for Policing in Northern Ireland (ICP, 1999; Topping, 2015). Even in 2018, the police reform process that created the Police Service of Northern Ireland (PSNI) retains its "near-mythic status", as a site "of pilgrimage for officials from around the world anxious to learn its lessons" (Mulcahy, 2008: 129). Yet, in the context of this reform narrative, and the vast accountability machinery that acts as a general guarantor to PSNI's status as the most overseen, human rights compliant police service in the western world (Topping, 2016), curious lacunae exist regarding specific police powers and practices and, in particular, those associated with stop and search. As arguably the most high-profile police power in England and Wales (Bowling and Philips, 2007; Bradford, 2017), stop and search has until recently been something of a 'non-issue' in Northern Ireland - politically, socially and operationally. Even recent developments in Scotland, where significant debate and contest has emerged, are yet to make it over the Irish Sea (Murray, 2014a, 2014b).

There are, we contend, two primary reasons for this lacuna. The first, related to the police reform process, is the political emphasis on policing in Northern Ireland being 'seen to be normal'. Significant energy has been invested by the PSNI and the wider policing structures in promoting the 'success' of community policing (a central plank the ICP reforms), cementing the centrality of good police-community relations (Topping, 2008). As we describe below, standard practice is transmuted into good practice, making difficult any discussion of standard policing tools that might somehow be 'problematic'.

The second reason is the persistent, if diminishing, terrorist threat in the country, currently classified as 'severe' by MI5 (Seymour, 2017). The ongoing (mainly dissident Republican) terrorist campaign against members of the PSNI and security forces has served to pull operational and political attention away from the mundanity of 'everyday' policing and 
focussed on the exigencies of national security (McDonald, 2017). This has, paradoxically, created something of a 'cool' policy climate - or perhaps micro-climate - in the otherwise 'hot' policing arena of Northern Ireland, allowing use of stop and search to grow in a way analogous to Scotland, prior to 2014 (Murray \& Harkin, 2017).

'Everyday' stop and search powers, amidst these twin pressures, have been prioritised down and out of sight, as an inconvenience to the loftier politics of policing being seen to 'be gotten right' (O'Rawe, 2003). This relative invisibility, in a way both like and unlike Scotland before Murray's (2014a) ground-breaking research, has persisted in the face of evidence that a recurrent problem with stop and search does exist (Bradford, 2017); countenanced by the fact the power has failed to have been referenced once in the past decade of policing plans set forth by the Northern Ireland Policing Board (NIPB) (Topping, 2017). But significantly, over the period 2004/5 - 2015/6 use of PACE-type stop and search in Northern Ireland has actually increased by $74 \%$, and is now used at a significantly higher rate than in England and Wales or Scotland (Bradford, 2017; Hargreaves, Husband and Linehan, 2017; PSNI, 2017b; Murray and Harkin, 2017).

In this article we provide an analysis of 'everyday' police stop and search powers in Northern Ireland. At a broad level, the paper examines what widespread use of stop and search powers indicate about the maintenance of social order in a highly contested, politically fractured context. The paper proceeds by exploring claims related to the utility of the power; the apparent futility of its use; and the dynamics which have helped render it 'invisible' from wider police oversight and scrutiny mechanisms.

As the first specific analysis of stop and search powers in PSNI's history, this paper does not - indeed cannot - answer why PSNI currently use stop and search powers at a higher level than any other police organisation in the United Kingdom. Rather, through extracting meaning from the patterns current use, we seek to open a window into the institutional 
dynamics underlying this coercive power, the use of which, as in many police forces in the United Kingdom, has become routine and ingrained (Bowling \& Marks, 2015). Ultimately, this paper seeks to understand how, within one of the most overseen policing jurisdictions in the world, 'normal' (non-terrorist) stop and search remains a relatively unchecked policing practice; simultaneously visible as a public affirmation of PSNI 'crime fighting' practice, yet invisible when set against the competing priorities of Northern Ireland's post-conflict policing landscape; and seemingly immune debate about its potentially iatrogenic effects (Bowling and Phillips, 2007; Topping, 2016; Topping and Schubotz, 2018).

\section{Contextualising Stop and Search in Northern Ireland}

Terrorist-related powers aside, Northern Ireland possesses, under the Police and Crime Evidence (Northern Ireland) Order 1989 and the Misuse of Drugs Act 1971 (c.f. Dickson, 2013), almost identical stop and search powers (and Codes of Practice) to those of England and Wales. Thus volume, proportionality and arrest rates in England and Wales provide legitimate points of comparison (Scotland is of course governed by yet another legal framework, rendering such comparisons slightly more difficult). However, while in England and Wales almost all (over 99\%) stops/searches are conducted under PACE-type legislation, in Northern Ireland only $70 \%$ of stops are carried out under such everyday powers (Hargreaves et al., 2017; PSNI, 2017b). The remaining 30\% are conducted mainly under the Northern Ireland-only Justice and Security (Northern Ireland) Act 2007 (JSA), and the Terrorism Act 2000. While the use of terrorist-related powers are quantitatively different to England and Wales - at least since the use of s.60 powers fell to very low levels in recent years (Hargreaves et al., 2017) in this paper we seek to avoid melding terrorist and 'normal' (PACE-type) stop and search powers into a single and potentially muddled profile. Rather, our focus remains on 'ordinary' stop and search powers because, as we argue, it is these that have been 'hidden' within the 
wider policing system. In stark contrast to the significant body of research dedicated to the various counter-terrorist powers utilised throughout the conflict and post-conflict periods, along with independent oversight of the JSA powers (c.f. Hillyard, 1988; McGovern and Tobin, 2010; Seymour, 2017), it is precisely the absence of policy attention directed at PACE-type stop and search which merits further investigation.

Indeed, in focusing on these 'ordinary' powers, they are governed by distinct and different legal principles compared to JSA powers. The former are based on reasonable suspicion, as in England/Wales, while the latter are 'suspicion-less', similar to the old s.44 Terrorism Act 2000 and s.60 Criminal Justice and Public Order Act 1994. Moreover, the JSA powers are for very specific purposes of finding munitions and wireless communications devices from suspected terrorist subjects. They tend to be directed at 'known' dissident republicans, and are often based on security-related intelligence (Seymour, 2017). It therefore appears that while there is inevitably some 'bleed across' between the two, the terrorist-based powers do indeed represent a different sort of power, and indeed a distinct sort of policing intent.

Consideration of the 'ordinary' stop and search powers in Northern Ireland can also usefully start with the 'importation' of PACE. While the political, civil and cultural context in 1989 bore little resemblance to that in England and Wales, the underpinning police organisational 'currency' of stop and search, and the extent of the 'mythical belief' in its efficacy remains a remarkable point of similarity (Bradford \& Loader, 2016). Police in Northern Ireland still cleave to the inherently 'deterrent' power of stop and search (in spite of its technically investigative basis), with the power construed as a multi-purpose tool capable of responding to almost any 'street-level' criminality (Bradford, 2017). In this respect, PSNI state the power is: 
'used to support the organisation's principle of keeping people safe (the duty of a police officer is set out in Section 32 Police (Northern Ireland) Act 2000). Successful use of these powers prevents crime and reduces the need for officers to use powers of arrest' (PSNI, 2017a: n.p).

Yet, missing in the country has been the ideological and political climate of England and Wales, generated by successive waves of: moral panics and ensuing discrimination (Hall et al., 1978; McPherson, 1999); Conservative/New Labour 'law and order' politics that provided for the growth and expansion of such powers during the $80 \mathrm{~s}, 90 \mathrm{~s}$ and $00 \mathrm{~s}$ (Garland, 2001); and the oversight, debate and contest that followed in a markedly cyclical fashion (Bradford, 2017). The climate of 'normal' stop and search in Northern Ireland has been instead marked by an absence of meaningful regulation or oversight, or indeed much debate and political attention at all.

\section{Use of the power(s)}

Overall use of stop and search powers in England and Wales has dropped from a peak of $1.2 \mathrm{~m}$ in $2010 / 11$ to 303,845 per year up to $2016 / 17$, averaging around 5 per 1000 of population per year $^{1}$ by the later period (Hargreaves et al., 2017). While underpinned by a differing legal and political circumstances, Scottish stop and search has also dropped from 64 per 1000 in 2010 to approximately 9 per 1000 over the same time frame (c.f. Lennon and Murray, 2016; Police Scotland, 2017). In contrast, the relatively limited and disparate publicly available data on PSNI's use of stop and search indicates that while as Figure 1 demonstrates there have been significant fluctuations in use of the power, with the rate peaking at 35 per 1000 population in 2009/10 before falling back, overall, numbers have remained largely static across this time, at

\footnotetext{
${ }^{1}$ Includes section 1 of PACE (1984) and section 60 of the Criminal Justice and Public Order Act 1994
} 
an average of approximately 31,000 stops per year. Including both PACE and terrorist related stops the stop rate was 17 per 1000 of population per year in 2016/17; and even removing terror-related stops, PACE-type stops were happening at an annual rate of approximately 13 per 1000 of population in that same year. In other words, the rate of stop and search conducted under 'normal' (non-terror related) legislation in Northern Ireland is now over twice the total rate for England and Wales; and 50\% greater than Scotland. As can be seen in Figure 2, the levels of stop and search across PSNI's eleven districts also vary dramatically.

\section{FIGURES 1 AND 2 ABOUT HERE}

Murray \& Harkin (2017) have recently argued that 'cold' and 'hot' climates can allow the growth of stop and search practices, on the one hand, or generate downward, restrictive political pressure, on the other. Derived from Loader and Sparks (2000) conceptualisation of 'cool' crime control policy climates, the term 'cool' might (from a police perspective) be substituted with 'favourable', insofar as it denotes a political and social environment of low interest and scrutiny, enabling 'business as usual', and practices that generate tension with specific groups or local communities to continue unchecked; because, bluntly, political attention is elsewhere. It is, in this regard, remarkable that the 'hyper-accountable', generally hot policing climate in Northern Ireland has allowed the levels of stop and search described above to flourish (Topping, 2016). Most obviously, given the general tension between police and working class Catholic and increasingly also Protestant communities (Topping, 2015), why has debate about this particularly intrusive police power not been sparked? Or, at least, why has there been a lack of social and political interest in this issue, as has been witnessed elsewhere in the United Kingdom in recent years? 
One answer to this puzzle could of course be that the PSNI is (uniquely) 'doing' stop and search 'right' - i.e. use the power in an effective, restrained, distributively fair and legitimate manner - and has thus simply been left by society to get on with the job. Yet as we describe below, there is no evidence that this is in fact the case, with stop and search used in an equally problematic, if slightly differential fashion, to elsewhere in the U.K. (Topping and Schubotz, 2018).

Another, more likely answer may lie in the very nature of the policing climate in Northern Ireland itself, which, while politically 'hot' at a general level can also be described as 'polluted' by the legacy of the conflict. This climate has further been subject to a dual process of 'sanitisation' and 'cooling' through the wider police reform processes (Ellison, 2007). Closely tied to the politics of the diminishing terrorist threat and community acceptance of the new policing order, mundane aspects of policing have by default been recoded into protected 'cool zones' - as an affirmation of 'normality' and thus not to be questioned because this very mundanity represents progress away from the past (Topping, 2015). There is significant political impetus to keep these pockets 'cool' and thus demonstrate just how 'normal' policing in Northern Ireland has become. Perhaps more prosaically, it is not surprising that 'everyday' policing receives relatively little attention in a context where the policing of the continuing security threat receives so much attention - and budget (Kearney, 2013; Belfast Newsletter, 2014). PACE-type stop and search has thus fallen into the interstices created by the policing and political energy expended on the twin pillars of police reform and the terrorist threat (with ongoing, associated, public disorder), perennially 'hot topics' which soak up resources, attention and oversight capital (Byrne, Jarman and Topping, 2013). This position has been further reinforced by a presumption that precisely because a robust system of police oversight and governance exists (Topping, 2016), everyday policing - as refracted through stop and search - must by default be 'properly' conducted, and it feeds into the necessary narratives 
of 'normalcy' which have had to been generated as part of the wider police reform process in the country (Mulcahy, 1999).

\section{Targeting the power(s)}

By far the most intractable problem with stop and search in England and Wales - and with cognate practices such as stop and frisk in the United States - is of course ethnic disproportionality in the application and experience of the power (Ariza, 2014; Bradford, 2017; Weber and Bowling, 2008). This appears to be much less of an issue in Northern Ireland, possibly for the reason that the ethnic minority population in the country is very small - just $1.8 \%$ of the total (Northern Ireland Statistics and Research Agency, 2012). Moreover, the correspondence between ethnic minority status, class and marginalisation is complicated by the deeply embedded distinctions between the two main Protestant and Catholic communities (c.f. Shirlow and Murtagh, 2006), such that in Northern Ireland being from a visible ethnic minority does not necessarily mark one out as being of special interest to the police in the same fashion as it may in the rest of the United Kingdom (Bradford, 2017).

This does not mean that the burden of stop and search falls equally across the population; nor is it to argue that ethnic disproportionality to stop and search does not exist (although public figures are not available). The most recent PSNI data and research does, however, suggest a picture of uneven and indeed disproportionate use of the power (FOI-201601181; Topping and Schubotz, 2018) - particularly in relation to age and gender. In fact, there exists over a decade of research highlighting this issue, which has, per the cold climate around every day policing noted above, been largely ignored.

This body of research has demonstrated repeated, arbitrary and potentially illegal use of stop and search against young males in socio-economically deprived areas (Nelson et al., 2010; Detail TV, 2017; Topping and Schubotz, 2018). Contact between young people and the 
police in Northern Ireland is particularly prominent in the study of Nelson et al (2010) who found that $70 \%$ of respondents in their research had experienced (largely negative) contact with PSNI. Children (under 18) comprised 17\% of all PSNI stop/searches under PACE-type powers in 2016/17, and based on current population estimates young males aged 15-17 are being stopped at a rate of approximately 82 per 1000 of population; and $18-25$ year old males at a rate of 117 per 1000 (PSNI, 2017b). Previous studies have found that $40 \%$ of children in North Belfast claimed to have been stopped by PSNI 'for no reason' (NIPB / Institute for Conflict Research, 2005), while $38 \%$ of children across the country reported 'disrespectful' behaviour when encountering the police (Nelson et al., 2010). And while the locations of stop and search encounters are not available at any finer granularity than district level, available evidence points to the fact that application of the power is predominantly located in socio-economically deprived communities (Hamilton et al., 2003; Nelson et al., 2010; The Detail TV, 2017; Topping and Schubotz, 2018). In sum, the current picture of stop and search in Northern Ireland would point to parallels with a pre-reform Scottish style of proactive policing focused on a young, suspect, socially marginal population.

It is therefore perhaps unsurprising that PSNI's overall arrest rate for stop and search sits at just $6 \%$, falling to $3 \%$ in some districts (see Figure 2), in stark contrast to the current arrest rate of 17\% for England and Wales (Hargreaves et al., 2017). The power is being used against children approximately 4000 times per year, totalling just over 28,000 stops involving children between 2010/11-2016/7. Yet in 2015/16 just 4.5\% of such stops resulted in further action where an item was found (arrest, caution, community resolution or report to the Public Prosecution Service - PSNI, 2016 FOI-2016-01181).

Such data provides only a small window into PSNI's stop and search practices. But with evidence of relatively high use, poor outcomes in terms of arrests, and the targeting of marginalised young males, the social, cultural and material contexts of stop and search in 
Northern Ireland raise familiar issues of police power, authority and structural inequality (McAlister et al., 2009). This picture is bolstered by the growing body of research that suggests the disruptive and/or deterrent effect of stop and search is, at best, marginal (McCandless et al., 2016; Rosenfeld and Fornango, 2014). Stop and search can be a useful part of hotspots and other highly targeted interventions, but evidence for its general utility remains markedly lacking (Tiratelli et al., 2018; Weisburd et al., 2015). While a definitive answer to the question of whether stop and search is 'effective' has yet to be forthcoming, the tenuous nature of its 'crime fighting' efficacy suggests, in an again familiar manner, that for PSNI the power fulfils some other role. Stop and search is not just, and cannot primarily be, about dealing with crime (Bradford \& Loader, 2016). Instead, its use is driven, at least in part, by an organisational impetus to bridge into, and discipline, unruly, recalcitrant populations (Choongh, 1998).

This is not of course how the police themselves necessarily see it. From the top to the bottom of police organisations across the UK, many officers have held firmly to the view that stop and search is a vital part of their crime-fighting armoury (Bradford, 2017). We should note from the perspective of individual officers this view is entirely understandable. Stop and search does uncover drugs, weapons and other contraband, and lead on occasion to arrest of serious offenders. PSNI's 2016/17 overall arrest rate of $6 \%$ of course yields some results in terms of preventing criminality. However, the criteria for judging the utility of stop and search, as a public display of police power and social control, may at police-organisational and political levels be weighted in favour of the symbolic rather than legal aspects of its use. Indeed, the enduring appeal of stop and search may be precisely because it is systematically and proactively targeted against certain 'others' (mainly young socio-economically marginal males) and does not, therefore, interfere with principles of inclusive citizenship and equality before the law as enjoyed by the 'law-abiding' majority (Murray, 2014). Both Fitzgerald et al. (2002) and Girling, Loader \& Sparks (2000) argue that public support for police use of stop 
and search remains firm - provided it is directed at the other. Thus, the very inequity of stop and search may actually shield police from objective scrutiny. It is directed at the 'usually suspect' minority while leaving the majority untouched (Reiman, 2004).

Judged by these standards, stop and search enacts, perhaps ironically in the context of Northern Irish police reform, a utilitarian principle that requires 'a discrete minority to relinquish their rights in the name of the greater good', without considering the material reality for those subject to the powers (Murray, 2014b: 295). The argument about the utility of stop and search is therefore inverted. Stop and search 'must' be effective because it is targeted at the 'right' people, those in need of deterrent/disruptive/disciplinary police interventions (Ward, Nicholas and Willoughby, 2011; Weaver, 2017). Such 'manufactured utility' is reflective of a supposition that for some sections of society, exposure to stop and search is an inevitable consequence of social circumstance and comportment (Flack, 2017). In particular, the utility of stop and search is derived from its capacity to deal with 'visible' young males, as the popular heuristic of criminal danger and an 'apprehendable threat' (Bradford, 2017; Young, 1999).

Commensurately, it would seem then that the principles underpinning Code of Practice $A$, which govern use of the power in Northern Ireland, are also being circumvented, organisationally reinterpreted or simply ignored (Bowling \& Phillips, 2007; Choongh, 1998; Department of Justice, 2015). With evidence demonstrating that the power is being used in technically illegal ways by PSNI, under minimal levels of actual - as opposed to notional regulation, and with little internal or external monitoring from the country's police accountability structures, stop and search appears to have been given the space to flourish in a 'cold' policy climate marked by high discretion and low scrutiny. The issues of legality and propriety around the use of stop and search is particularly acute in relation to children. Topping and Schubotz (2018) detail, in their nationally representative survey of Northern Irish 16 year olds, that in $88 \%$ of stop and search encounters experienced by this group, officers did not 
provide identifying details; and in $90 \%$ of cases, no record was made on an electronic device, nor reference number or receipt given. These statistics remain particularly salient in view of the fact stop/search is of course, meant to be governed under Code of Practice A. Moreover, $34 \%$ of respondents reported that friends or classmates had been subject to stop/search in the previous twelve months, which would further suggest greater use of the power against young people than is officially acknowledged (Topping and Schubotz, 2018).

This absence of coordinated monitoring of PSNI's PACE-type stop and search powers has been enabled by, as well as contributed to, the cold policy climate. There has also been a form of systemic deference to PSNI authority around stop and search. For example, the PSNI have since 2011 provided restricted quarterly stop and search statistics, with breakdowns by age, to the Northern Ireland Policing Board (NIPB). This data has not been seen as problematic by the main statutory oversight and monitoring body (NIPB, 2013), which has not, at least publicly, discussed this issue in any depth. Yet, in response to use of stop and search against children, PSNI have recently claimed: 'We have process in place to ensure stop and search powers are used properly, legitimately and proportionately in preventing and detecting crime' (The Detail TV, 2017). The existence of regulatory oversight, however notional it is in practice, is used to defend the way the power is used.

\section{The Damage Done}

'Many of the young people detailed negative experiences of interaction with the PSNI as a standard feature... being subjected to stop and search, being 'moved on for no apparent reason'...as 'low-level harassment'...such experiences were perceived as a standard, routine feature of policing and in particular in the way that the police treated young people' (Byrne et al., 2013: 74). 
A key objective for policing in Northern Ireland over the past fifteen years has been the need to establish the legitimacy of, and public support for, the PSNI, especially across the sectarian divides (c.f. Ellison, 2007; Mulcahy, 2006; Topping, 2008; 2015). A question seldom asked, though, relates to the potentially corrosive effect of 'everyday' stop and search upon that very community trust and police legitimacy. Indeed, it is perhaps futile to suggest those socio-economically deprived areas in Northern Ireland where stop and search is clustered would not exhibit dissatisfaction and distrust in the police, as is the case elsewhere in the U.K. when the power has been overused (McAra \& McVie, 2005).

The evidence of disproportionate use of the power against young males in deprived neighbourhoods by PSNI may further be defined as a form of 'interactional' discrimination, with the power used more liberally upon such citizens simply by virtue of being young, male and from a socio-economically deprived area (Reiner, 2010; Topping and Schubotz, 2018). In turn, a process may be engaged where young males in those areas fuse practical policing experiences with the contested history and politics of policing in Northern Ireland to develop and reinforce distinctively anti-police beliefs, ideologies and identities, profoundly affecting the way they interact with PSNI (McAlister, Scraton \& Haydon, 2009). A 'ratchet effect' is thus created, whereby interactions become more confrontational, reducing cooperation and information flows to police. Stop and search therefore becomes one of the few avenues for police to engage with that population (Hardcourt, 2004). This argument is in part substantiated through PSNI's internal Youth Justice Service Instruction SI0817, which states that stop and search should be used as an 'opportunity' to build a relationship with children, advising: 'Our conduct may be an opportunity to develop relations with children during these exchanges (PSNI, 2017c: 9) - assuming that confrontational, enforcement-led practice is an appropriate means to do so. Indeed, little appears to have changed in almost 25 years in terms of police 
engagement with young people in Northern Ireland, where perceived harassment, targeting and arbitrary contact persist as recurring themes (McVeigh, 1994).

The negative effects of stop and search against young people are well documented in the literature (e.g. Flacks, 2017; McAra and McVie, 2005; Wiley \& Esbenson, 2016). Yet Northern Ireland presents a particularly troubling location when considering the iatrogenic effects of the power (Bowling \& Marks, 2015). Evidence points to the fact that stop and search has the effect, on average, of undermining trust and legitimacy, an idea that is rendered particularly salient in a context marked by long traditions of violent and non-violent self-help collectivism (Topping \& Byrne, 2016). Individuals who invest less legitimacy in the police may be more likely to engage in self-help violence and 'street justice' (Black, 1998; Home Office Select Committee, 2007; Jackson et al., 2013). And recent research from Northern Ireland has moreover demonstrated that hostile and confrontational styles of policing, such as that associated with stop and search, can actually lead to violence against the PSNI between police and children / young people. This was particularly evident in the study of Byrne et al (2013) whereby stop and search was cited as a causal factor for attacking PSNI as part of wider public order situations.

The (In) visibility of Stop and Search Powers

'They don't know why they have been singled out, they feel they have been victimised when it happens and they certainly feel they are being labelled as well. Very few would even attempt put a complaint in, they don't see the point. They would say 'who would believe me over a police officer?', (Belfast youth worker, quoted in Campbell, 2017). 
Having explored both the utility and futility of PSNI's use of stop and search, our final question relates to the dynamics which have helped render the power as a relatively 'unseen' policing practice. We claim above that stop and search remains a 'hidden' issue within the multiplicity of much lauded police oversight bodies in Northern Ireland (Topping, 2016). Research evidence on stop and search in Northern Ireland does exist - and has apparently been ignored. It is therefore vital to consider what other factors have led to PSNI's stop and search practices to remain hidden in plain sight (Bridges, 2015).

The issue of 'where' stop/searches are happening is likely to be a key condition for this (in)visibility. Politics and history aside, Northern Ireland remains similar in terms of patterns of poverty and social exclusion to England and Wales (Child Poverty Alliance, 2014). There are marked pockets of deprivation, distinct from surrounding areas, further identified by the extreme ethno-religious segregation still found in many parts of Northern Ireland (Wilson, 2016). Existing literature also reflects that reactions to young people in (and from) deprived urban areas in the country are, like elsewhere, symbolic of anxieties about street crime, deviance and anti-social behaviours (Young, 1999; McAlister et al., 2009; McAra \& McVie, 2005). It is those areas where 'suspect' young people live which are then subject to geographic 'recoding' by PSNI, and defined by attributions of criminal propensity (McAlister et al., 2009) - a point supported by the most recent survey data which demonstrates PSNI direct more stop and search attention toward more deprived areas (Topping and Schubotz, 2018). This geographic 'recoding' is further reinforced whereby low socio-economic status, 'hanging out' in public space, previous police contact, lower educational attainment, unemployment, living in social housing and health problems have all been linked to the increased propensity of an individual being stopped by the police (Murray, 2014a). There is no reason to expect Northern Ireland to be any different here. 
As the structural basis for the 'availability pool' of 'usual suspects', these geographic areas and communities are then further reified into 'stop zones' (Bowling \& Phillips, 2007). As argued elsewhere, certain sections of society, such as young people, can only really be available to police in such areas - with evidence demonstrating young people living in more middle-class areas are not subject to police attention to anything like the same extent (Bradford, 2017; Topping and Schubotz, 2018).

In sum, while PSNI do not publicly release stop and search figures to finer geographic detail than district level, there is much to suggest that while the power is situationally visible for those who experience it (and perhaps highly so), the areas within which stops are concentrated are subject to low overall social visibility, at least to the extent they are defined as criminogenic, 'othered' and beyond the pale, and geographically and socially segregated from other areas much less affected by police use of the power. The invisibility of the power, is thus fostered by a combination of socio-economic and cultural segregation (Topping and Schubotz, 2018), providing additional, 'shielding capital' for use of stop and search.

As detailed above, while the power has the potential to be used to harass and punish young people, viable sources of redress are - again ironically in the wider context of Northern Irish police accountability - marked by their absence. This is especially true at the individual level, where there are few avenues available for reproach against officers who do not use the power within its legally defined limits, as noted above (Roberson \& Mire, 2010). Young people's negative experiences of stop and search are not gaining (or being afforded opportunities for) sufficient recognition through official policing channels (Hamilton et al., 2003; OPONI, 2015).

Within this 'permissive' policing environment the balance between the police and individual has been calibrated to create, by default, benefit of the doubt for PSNI, sheltering criticism or debate (Lennon \& Murray, 2016; Loader, 1996). Indeed, the practical reality on 
the ground is not so much that police practice deviates from the law or civil liberties per se, but that these rights do not appear relevant in relation to some individuals: the young, socioeconomically deprived males who bear the brunt of the practice.

\section{What's the point of stop and search?}

Returning to our original epistemological question, the evidence presented points to disproportional use of stop and search by PSNI directed at marginalised groups in society; in turn generating tension between police and, at the very least, those regularly singled out for this kind of attention. As noted, there is also little evidence that it is has any general, overall, effect on crime, here as elsewhere. How then can be think about the wider sociological function of this power in this context? What precisely is it 'for'?

Justice and Meares' (2014) concepts of the 'overt' and 'covert' aspects of the criminal justice 'curriculum' provide significant insight here. As they describe, the criminal justice system may be viewed as an engine of social conditioning, which, through its various communicative aspects (e.g. decisions on which laws are enforced on whom, when, and how such practices are justified and communicated), educates citizens on the 'quality' of the law, the aims of the state, and their position in society. The 'overt' curriculum is denoted here by the PSNI's rational policy justification for stop and search, the constraints of PACE Code of Practice A, and the ideological presentation of stop and search as 'keeping people safe' (PSNI, 2017a). This framework positions the power as precisely 'normal' - well regulated, restrained, and targeted appropriately - as a psycho-social defence of stop and search that is related to perceived public opinion, sentiment and expectation around its role in bringing about safer communities (c.f. Delsol and Shiner, 2015). The overt curricula is also inextricably linked to the regulative human rights-framework which underpins policing (and thus, in theory, stop and search) activity in Northern Ireland (Ellison, 2007). Mundane 'legal' police practices may serve 
to further demarcate an unquestionable rule-of-law 'territory' properly controlled by the police, additionally highlighting the inappropriateness of attempts at governance made by non-state actors - of which Northern Ireland has a long tradition (Hamill, 2011; Topping and Byrne, 2016).

The 'covert' curriculum of criminal justice, however, provides for a different assessment. Evidence suggests use of stop and search is concentrated on certain groups, and that it is not sufficiently constrained in law or in practice (Committee on the Administration of Justice, 2012). Those on the receiving end of the (relatively) high levels of stop and search in Northern Ireland likely experience a different story to that provided by the overt narrative outlined above. Rather than proclaiming the monopoly power of the state to assert normative order - something which necessarily encompasses all citizens equally - stop and search as it occurs 'on the ground' categorizes, distinguishes, and excludes. Above all, and in a very familiar way, this is about PSNI marking particular groups out as 'police property' (Loader, 1996). Stop and search serves to educate members of these groups in their subaltern status.

What is notable is the complementarity of these ideas. It is not the case that either the overt or the covert curricula holds sway, but rather that both fulfil important, simultaneous roles. As Justice and Meares (2014) describe in the US context, both curricula conduct useful work for the state, presenting on the one hand a set of overt, legitimating myths; and on the other hand, a covert power to categorise and control recalcitrant populations.

\section{Conclusion}

It seems to us that PSNI's use of stop and search oscillates between the overt ('now you see it) and covert ('now you don't'). On the one hand, despite the relative 'stability' of stop and search in Northern Ireland, certainly compared with the rest of the United Kingdom, events elsewhere provide tentative cause for optimism, at least insofar as an ingrained way of 'doing' 
policing can be subject to positive change where 'covert' (and damaging) usage patterns are rendered visible (Murray and Harkin, 2017). On the other hand, it is concerning that the basic power to stop and search, as espoused through PACE, has the capacity to evade scrutiny within this most overseen policing context and is seemingly immune to (a lack of) evidence of effectiveness. Both police and oversight bodies appear blind to the damaging effect the power can have on police-community relations. This remains an elusive power, hard to pin down within established regulatory and accountability structures.

The evidence presented above also supports the argument that stop and search should be positioned as an amplificatory instrument for 'cop culture', and a product and producer of poor community relations and the politics of policing being seen to be 'done'. Breaking PSNI's dependence on its stop and search 'habit', as partially - and contingently - achieved elsewhere in the U.K (Travis, 2014) will require not just additional technical scrutiny but also wider political and policy leverage (Murray and Harkin, 2017). As the first in-depth analysis of PACE-type stop and search in PSNI's seventeen-year history, we hope this paper provides an initial step towards more a critical debate in this area. 


\section{References}

Ariza, JJM (2014) Police initiated contacts: young people, ethnicity, and the 'usual suspects'. Policing and Society 24(2): 208-223

Belfast News Letter (2014) Third of police budget spent on terrorism, parades and disorder. $24^{\text {th }}$ February. Available at:

http://www.newsletter.co.uk/news/crime/third-of-police-budget-spent-tackling-terrorismparades-and-disorder-1-5898105 (accessed 15 May 2018)

Black, D (1998) The Social Structure of Right and Wrong. San Diego: Academic Press.

Bowling B and Marks E (2015) Towards a transnational and comparative approach. in Delsol R and Shiner M (eds) Stop and Search: The Anatomy of a Police Power. Basingstoke: Palgrave MacMillan, pp.170-192.

Bowling B and Phillips C (2007) Disproportionate and discriminatory: reviewing the evidence on police stop and search. Modern Law Review 70(6): 936-961.

Bradford B (2015) Unintended consequences. In Delsol, R and Shiner, M (eds) Stop and Search: The Anatomy of a Police Powers. Basingstoke: Palgrave Macmillan, pp.102-122.

Bradford B (2017) Stop and Search and Policing Legitimacy. Abingdon: Routledge.

Bradford B and Loader I (2016) Police, crime and order: the case of stop and search. In Bradford B Jaurengi, B Loader I and Steinberg J (eds.) The SAGE Handbook of Global Policing. London: Sage Publications, pp.241-260

Brewer J (2001) The growth, extent and causes of crime: Northern Ireland. In: Shaw M (ed) Crime and Policing in Transitional Societies Seminar Report. Johannesburg, South Africa: KAS, pp.103-110.

Bridges L (2015) The legal powers and their limits. In Delsol R and Shiner M (eds) Stop and Search: The Anatomy of a Police Power. Basingstoke: Palgrave Macmillan, pp.9-30.

Byrne J Jarman N and Topping J (2013) Community perspectives on public order policing. Ulster University / Institute for Conflict Research. Unpublished research report, commissioned by Police Service of Northern Ireland.

Campbell C (2017) PSNI search thousands of under-18s, but few arrests made. The Irish Times, $29^{\text {th }}$ March. Available at:

https://www.irishtimes.com/news/crime-and-law/psni-searches-thousands-of-under-18s-butfew-arrests-made-1.3028818 (accessed 15 May 2018).

Child Poverty Alliance (2014) Beneath the Surface: Child Poverty in Northern Ireland. Available at: http://www.ci-ni.org.uk/DatabaseDocs/nav_991889_cpa_presentation.pdf (accessed 15 May 2018).

Choonagh S (1998) Policing the dross. A social disciplinary model of policing. British Journal of Criminology 38(4): 623-634. 
Committee on the Administration of Justice (2012) Still part of life here? A report on the use and misuse of stop and search / question powers in Northern Ireland. Belfast: Committee on the Administration of Justice.

Delsol, R and Shiner, M (eds) Stop and Search: The Anatomy of a Police Powers. Basingstoke: Palgrave Macmillan

Department of Justice Northern Ireland (2015) Police and criminal evidence (Northern Ireland) Order 1989 code A. Code of practice for the exercise by police officers of statutory powers of stop and search. Available at:

https://www.justice-ni.gov.uk/sites/default/files/publications/doj/pace-code-a-2015.pdf

(accessed 15 May 2018).

Dickson B (2013) Law in Northern Ireland (2 ${ }^{\text {nd }}$ ed.). Oxford: Hart Publishing

Ellison G (2007) A blueprint for democratic policing anywhere in the world: Police reform, political transition, and conflict resolution in Northern Ireland. Police Quarterly 10(3): 243269.

Fitzgerald M Hough M Joseph J and Qureshi T (2002) Policing for London. Cullompton: Willan Publishing.

Flacks S (2017) The stop and search of minors: a 'vital police tool'? Criminology and criminal justice, published $12^{\text {th }}$ July. Available at:

http://dx.doi.org/10.1177\%2F1748895817720485

Garland D (2001) The Culture of Control: Crime and Social Order in Contemporary Society. Oxford University Press.

Girling E Loader I and Sparks R (2000) Crime and Social Change in Middle England. London: Routledge.

Hall S Critcher C Jefferson T Clarke J and Roberts B (1978) Policing the Crisis: Mugging, the State and Law and Order. London and Basingstoke: The Macmillan Press ltd.

Hamill H (2011) The Hoods: Crime and Punishment in Belfast. Princeton: Princeton University Press.

Hamilton J Radford K and Jarman N (2003) Policing, accountability and young people. Belfast: Institute for Conflict Research. Available at:

http://conflictresearch.org.uk/reports/policing/NIPB-PONI-Young-People-April-2003.pdf (accessed 15 May 2018).

Harcourt B (2004) Rethinking race profiling: a critique of the economics, civil liberties, and constitutional literature, and of criminal profiling more generally. The University of Chicago Law review 71(4): 1329-1330.

Hargreaves J Husband H and Linehan C (2017) Police powers and procedures, England and Wales, year ending $31^{\text {st }}$ March 2017. London: Home Office. Available at: 
https://www.gov.uk/government/uploads/system/uploads/attachment data/file/658099/police -powers-procedures-mar17-hosb2017.pdf (accessed 15 May 2018).

Hillyard P (1988) Political and social dimensions of emergency law in Northern Ireland. In Jennings A (ed) Justice Under Fire: The Abuse of Civil Liberties in Northern Ireland. London: Pluto Press, pp.191-212.

Home Office Select Committee (2007) Young Black People and the Criminal Justice System HC 181-I. London: House of Commons. Available at: https://publications.parliament.uk/pa/cm200607/cmselect/cmhaff/181/181i.pdf (accessed 15 May 2018)

Jackson J Huq A Bradford B and Tyler TR (2013) Monopolizing force? Police legitimacy and public attitudes towards the acceptability of violence. Psychology, Public Policy and Law 19(4): 479-497.

Justice B and Meares TL (2014) How the criminal justice system educates its citizens. The Annals of the American Academy 651, January, 159-177.

Kearney V (2013) Protest and riot policing costing PSNI over $£ 3 \mathrm{~m}$ a month. $B B C N I, 4^{\text {th }}$ September. Available at: http://www.bbc.co.uk/news/uk-northern-ireland-23966384 (accessed 15 May 2018).

Lennon G and Murray K (2016) Under-regulated and unaccountable? Explaining variations in stop and search rates in Scotland, England and Wales. Policing and society, DOI: 10.1080/10439463.2016.1163359

Loader I (1996) Youth, Policing and Democracy. Basingstoke: Palgrave Macmillan.

Loader I and Sparks R (2010) Public Criminology? London: Routledge.

Lustgarten L (2002) The future of stop and search. Criminal Law Review, 603-618.

McAlister S Scraton P and Haydon D (2009) Childhood in Transition: Experiencing Marginalisation and Conflict in Northern Ireland. Belfast: Queen's University Belfast / Save the Children / Prince's Trust. Available at: https://pure.qub.ac.uk/portal/en/publications/childhood-in-transition-experiencingmarginalisation-and-conflict-in-northern-ireland(720c8cb9-671b-4f2e-9995b934a1cb3760).html (accessed 15 May 2018).

McAra L and McVie S (2005) The usual suspects? Street-life, young people and the police. Criminal Justice 5(1): 5-36.

McCandless R Feist A Allan J and Morgan N (2016) Do initiatives involving substantial increases in stop and search reduce crime? Assessing the impact of operation BLUNT 2. London: Home Office.

McDonald H (2017) Belfast officer injured in drive-by shooting. The Guardian, $22^{\text {nd }}$ January, available at: https://www.theguardian.com/uk-news/2017/jan/22/belfast-police-officerinjured-in-terrorist-shooting (accessed 15 May 2018). 
McGovern M and Tobin A (2010) Countering terror or counter-productive: comparing Irish and British Muslim experiences of counter-insurgency law and policy. Report of a Symposium, Belfast/Edge Hill University. Available at:

https://repository.edgehill.ac.uk/2141/1/Countering_Terror_or_Counter-

Productive_Pdf_November_2010.pdf (accessed 15 May 2018).

McPherson W (1999) The Stephen Lawrence Inquiry: Report of an Inquiry by Sir William McPherson of Cluny. Cm. 4262-I. Available at:

https://www.gov.uk/government/uploads/system/uploads/attachment_data/file/277111/4262.p df (accessed 15 May 2018).

McVeigh, R (1994) It's Part of Life Here: Security Forces and Harassment in Northern Ireland, Based on a Survey of Young People. Belfast: Committee on the Administration of Justice.

Mulcahy A (1999) Visions of normality: peace and the reconstruction of policing in Northern Ireland. Social and Legal Studies 8(2): 277-295.

Mulcahy A (2006) Policing in Northern Ireland: Conflict, Legitimacy and Reform. Devon: Willan Publishing.

Mulcahy A (2008) Community Policing in Contested Settings: The Patten Report and police reform in Northern Ireland. In Williamson T (ed) The Handbook of Knowledge-Based Policing: Current Conceptions and Future Directions. Chichester: Wiley, pp. 117-137.

Murray K (2014a) Stop and search in Scotland: an evaluation of police practice. SSCJR Report 01/2014: Scottish Centre for Crime and Justice Research. Available at:

http://www.sccjr.ac.uk/publications/stop-and-search-in-scotland-an-evaluation-of-policepractice/ (accessed 15 May 2018).

Murray K (2014b) The practice turn: stop and search in Scotland (a study in elite power). PhD thesis, Edinburgh University, UK.

Murray K (2016) Understanding and preventing youth crime survey (UPYC) early findings stop and search in Glasgow and Edinburgh. The University of Edinburgh. Available at:

http://www.spa.police.uk/assets/128635/352708/uypcstopandsearch (accessed 15 May 2018).

Murray K (2017) The modern making of stop and search: the rise of preventative sensibilities in post-war Britain. British Journal of Criminology 58(3): 588-605.

Murray K and Harkin D (2017) Policing in cool and hot climates: legitimacy, power and the rise and fall of mass stop and search in Scotland. British Journal of Criminology 57(4): 885905

Nelson E McBride R O'Riordan O and Smyth P (2010) Beyond the margins: building trust in policing with young people. Belfast: Institute for Conflict Research. Available at: http://conflictresearch.org.uk/reports/policing/Beyond-the-Margins-Building-Trust-inPolicing-With-Young-People.pdf (accessed 15 May 2018). 
Northern Ireland Policing Board (2013) Human rights thematic review: policing with children and young people. Update on PSNI Implementation of recommendations. Belfast: NIPB. Available at: https://www.nipolicingboard.org.uk/sites/nipb/files/media-files/human-rightsthematic-review-policing-with-children.pdf (accessed 15 May 2018).

Northern Ireland Policing Board / Institute for Conflict Research (2005) Young people's attitudes and experiences of policing, violence and community safety in north Belfast. Belfast: Institute for Conflict Research. Available at:

http://conflictresearch.org.uk/reports/young-people/NIPB-North-Belfast-Youth-Survey.pdf (accessed 15 May 2018).

Northern Ireland Statistics and Research Agency 2012. Census 2011 key statistics for Northern Ireland. Belfast: NISRA. Available at:

https://www.nisra.gov.uk/sites/nisra.gov.uk/files/publications/2011-census-results-keystatistics-northern-ireland-report-11-december-2012.pdf(accessed 15 May 2018).

O'Rawe M (2003) Transitional policing arrangements in Northern Ireland: the can't and won't of change dialect. Fordham International Law Journal 22: 1015-1073.

Office of the Police Ombudsman for Northern Ireland, 2015. School pupil's awareness of the Office of the Police Ombudsman for Northern Ireland: results from the 2013 young person's behaviour and attitudes survey. Belfast: OPONI. Available at:

https://policeombudsman.org/getmedia/65352b67-023c-453a-a926-d65e96f7aecc/YPBAS2013-report.pdf (accessed 15 May 2018).

Police Service of Northern Ireland (2017a) Advice and Information: Stop and Search. Available at: https://www.psni.police.uk/advice information/stop-and-search// (accessed 15 May 2018).

Police Service of Northern Ireland (2017b) Stop and search statistics financial year 2016/17. Available at:

https://www.psni.police.uk/globalassets/inside-the-psni/our-statistics/stop-and-searchstatistics/2016/march/2016-17-fy-stop-and-search-report-official---public.pdf (accessed 15 May 2018).

Police Service of Northern Ireland (2017c) SI0817 Youth justice service instruction. Available at: https://www.psni.police.uk/globalassets/advice--information/our-publications/policiesand-service-procedures/youth-justice---external-120517.pdf (accessed 15 May 2018).

Police Scotland (2017) Stop and search data publication. Available at:

http://www.scotland.police.uk/about-us/police-scotland/stop-and-search/stop-and-searchdata-publication/ (accessed 15 May 2018).

Reiman J (2004) The Rich Get Richer and the Poor Get Prison. Ideology, Class and Criminal Justice. Boston: Pearson.

Reiner R (2010) The Politics of the Police ( $4^{\text {th }}$ ed.). Oxford: Oxford University Press.

Report of the Independent Commission on Policing for Northern Ireland (1999) A New Beginning: Policing in Northern Ireland. Belfast: HMSO. 
Roberson C and Mire S (2010) Ethics for Criminal Justice Professionals. Boca Raton: CRC Press.

Rosenfeld R and Fornango R (2014) The impact of police stops on precinct robbery and burglary rates in New York City, 2003-2010. Justice Quarterly 31(1): 6-122.

Seymour D (2017) Report of the Independent Reviewer: Justice and Security (Northern Ireland) Act $20079^{\text {th }}$ report: $1^{\text {st }}$ August. London: HMSO.

Shirlow P and Murtagh B (2006) Belfast: Segregation, Violence and the City. London: Pluto Press.

The Detail TV (2017) PSNI urged to reconsider use of stop and search on under-18s. Available at: $\quad$ http://www.thedetail.tv/articles/psni-urged-to-reconsider-use-of-stop-and-search-onchildren (accessed 15 May 2018).

Tiratelli M Quinton P and Bradford B (2018) Does stop and search deter crime? Evidence from ten years of London-wide data. The British Journal of Criminology azx085, https://doi.org/10.1093/bjc/azx085

Topping JR (2008) Community policing in Northern Ireland: a resistance narrative. Policing and Society 18(4): 377-398.

Topping JR (2015) Policing in transition. In Dwyer C and McAlinden A(eds) Criminal Justice in Transition: The Northern Ireland Context. Oxford: Hart Publishing, pp.109-130.

Topping JR (2016) Accountability, policing and the PSNI: Leading globally, limited locally?. In Lister S and Rowe M (eds) Accountability and Policing. Oxon: Routledge, pp.150-171.

Topping JR (2017) 'What's wrong with children? Stop and search as a barometer of young people's treatment in a post-conflict landscape. In: European Society of Criminology, Cardiff, UK, $13^{\text {th }}-16^{\text {th }}$ September.

Topping JR and Byrne J (2016) Shadow policing: The boundaries of community-based 'policing' in Northern Ireland. Policing and Society 26(5): 522-543.

Topping JR and Schubotz D (2018) The usual suspects?: Young people's experiences of police stop and search powers in Northern Ireland. Belfast: Queen's University Belfast / Ulster University. Available at: http://www.ark.ac.uk/ylt/results/ (accessed 15 May 2018).

Travis A (2014) Teresa May announces reform of police stop-and-search powers. The Guardian $30^{\text {th }}$ April. Available at:

https://www.theguardian.com/law/2014/apr/30/theresa-may-reform-police-stop-and-searchpowers (accessed 15 May 2018).

Ward L Nicholas S and Willoughby M (2011) An assessment of the tackling knives and serious youth violence action programme (TKAP) - phase II. Research Report 53. London: Home Office. 
Weaver M (2017) Met police chief says more stop and search may help reduce knife crime. The Guardian, $8^{\text {th }}$ August. Available at:

https://www.theguardian.com/law/2017/aug/08/met-police-chief-stop-and-search-increasereduce-knife-crime-cressida-dick (accessed 15 May 2018).

Weber L and Bowling B (2008) Valiant beggars and global vagabonds: Select, eject, immobilise. Theoretical Criminology 12(3): 355-375.

Weisburd D Wooditch A Weisburd T and Yang S-M (2015) Do stop, question and frisk practices deter crime? Evidence from microunits of space and time. Criminology and Public Policy 15(1):31-56.

Wiley SA and Esbeusen FA (2016) The effect of police contact: does official intervention result in deviance amplification? Crime and Delinquency 62(3): 283-307.

Wilson R (2016) Northern Ireland Peace Monitoring Report Number Four. Belfast: Community Relations Council. Available at: https://www.communityrelations.org.uk/sites/crc/files/media-files/NIPMR-Final-2016.pdf (accessed 15 May 2018).

Young, J., 1999. The Exclusive Society. London: Sage Publications. 


\section{FIGURE 1}

PSNI Ten Year Trend of Stop and Search Powers 2004/5 - 2016/17 (Seymour, 2017; PSNI, 2017b)

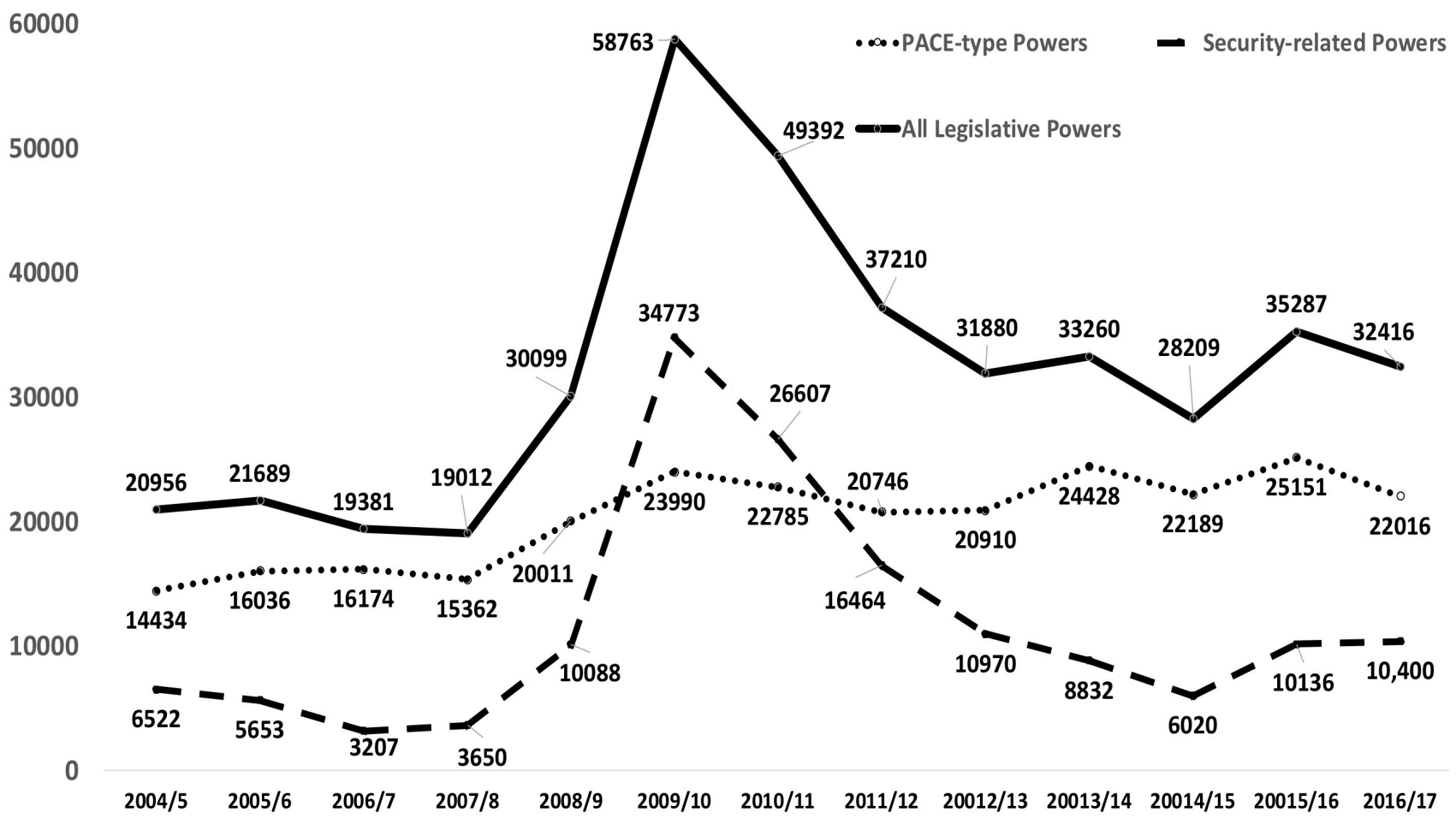




\section{FIGURE 2}

Police Service of Northern Ireland Stop and Search Statistics by District 2016/17 (all powers)* (PSNI, 2017b)

\begin{tabular}{|c|c|c|c|}
\hline PSNI District & $\begin{array}{l}\text { Arrest } \\
\text { Rate }\end{array}$ & $\begin{array}{c}\text { Stop \& Search } \\
\text { rate } \\
\text { per } 1000 \\
\text { population } \\
\end{array}$ & $\begin{array}{c}\text { Crimes per } 1000 \\
\text { population }\end{array}$ \\
\hline Antrim \& Newtownabbey & $5.6 \%$ & 10.7 & 48.9 \\
\hline Ards \& North Down & $5.4 \%$ & 5.6 & 39.1 \\
\hline Belfast City & $9 \%$ & 27.2 & 105.1 \\
\hline Causeway Coast \& Glens & $5.1 \%$ & 15.3 & 43.9 \\
\hline $\begin{array}{c}\text { Armagh, Banbridge } \& \\
\text { Craigavon }\end{array}$ & $5.4 \%$ & 17 & 47.8 \\
\hline Derry City \& Strabane & $3.7 \%$ & 25.1 & 62.7 \\
\hline Fermanagh \& Omagh & $8.3 \%$ & 11.5 & 43.1 \\
\hline Lisburn \& Castlereagh & $6.7 \%$ & 21.5 & 42.2 \\
\hline Mid \& East Antrim & $3.3 \%$ & 15.9 & 40.3 \\
\hline Mid Ulster & $5.5 \%$ & 11.5 & 34.6 \\
\hline Newry \& Mourne & $3.5 \%$ & 16.1 & 49.4 \\
\hline
\end{tabular}

*separation of PACE / non-PACE powers not available at district level 